\title{
The Role of Corticotropin-Releasing Factor and Corticosterone in Stress- and Cocaine-Induced Relapse to Cocaine Seeking in Rats
}

\author{
Suzanne Erb, ${ }^{1}$ Yavin Shaham, ${ }^{2}$ and Jane Stewart ${ }^{1}$ \\ ${ }^{1}$ Center for Studies in Behavioral Neurobiology, Department of Psychology, Concordia University, Montreal, Quebec, \\ Canada, H3G 1M8, and 2Biobehavioral Research Department, Addiction Research Foundation, Toronto, Ontario, Canada \\ M5S 2S1, and Department of Psychology, University of Toronto
}

\begin{abstract}
We have shown previously that footshock stress and priming injections of cocaine reinstate cocaine seeking in rats after prolonged drug-free periods (Erb et al., 1996). Here we examined the role of brain corticotropin-releasing factor (CRF) and the adrenal hormone corticosterone in stress- and cocaineinduced reinstatement of cocaine seeking in rats. The ability of footshock stress and priming injections of cocaine to induce relapse to cocaine seeking was studied after intracerebroventricular infusions of the CRF receptor antagonist D-Phe $\mathrm{CRF}_{12-41}$, after adrenalectomy, and after adrenalectomy with corticosterone replacement. Rats were allowed to selfadminister cocaine ( $1.0 \mathrm{mg} / \mathrm{kg} /$ infusion, i.v) for $3 \mathrm{hr}$ daily for 10-14 $\mathrm{d}$ and were then placed on an extinction schedule during which saline was substituted for cocaine. Tests for reinstatement were given after intermittent footshock (10 min; $0.5 \mathrm{~mA}$ ) and after priming injections of saline and cocaine $(20 \mathrm{mg} / \mathrm{kg}$,
\end{abstract}

In individuals with a history of cocaine self-administration, relapse to cocaine taking, even after prolonged periods of abstinence, is highly probable and remains the most difficult challenge for treatment. Little is known about the specific environmental factors that lead to relapse or about the neurobiological changes that may leave individuals vulnerable to relapse, but it is known that a "taste" of the drug itself can increase craving for cocaine in drug-free addicts (Jaffe et al., 1989) and reinstate drug seeking after periods of extinction in cocaine-experienced animals (de Wit and Stewart, 1981; Comer et al., 1995; Erb et al., 1996; Self et al., 1996). Recently we (Erb et al., 1996) and others (Ahmed and Koob, 1997) have shown, using an animal model of relapse, that brief exposure to a stressor, long considered important for relapse in humans (Shiffman and Wills, 1985; Kosten et al., 1986; McFall et al., 1992), is a powerful stimulus for reinstatement of cocaine seeking after extended drug-free periods, just as it is for the reinstatement of heroin seeking (Shaham and Stewart, 1995). Furthermore, we found that in animals trained to self-administer cocaine, stress-induced relapse can be attenuated by systemic

Received March 5, 1998; revised April 27, 1998; accepted April 30, 1998.

This work was supported by grants from the National Institute of Drug Abuse, the Medical Research Council of Canada, and Fonds pour la Formation de Chercheurs et l'Aide la Recherche (Quebec). S.E. was supported by graduate fellowships from the Natural Science and Engineering Research Council of Canada and Concordia University. We thank Demetra Rodaros, Natalina Salmaso, and Douglas Funk for their assistance, Claire-Dominique Walker for the corticosterone determinations, and Jean Rivier of the Salk Institute for the generous gift of D-Phe $\mathrm{CRF}_{12-41}$.

Correspondence should be addressed to Dr. Jane Stewart, Center for Studies in Behavioral Neurobiology, Department of Psychology, Concordia University, 1455 de Maisonneuve Boulevard, Montreal, Quebec, Canada, H3G 1M8.

Copyright (C) 1998 Society for Neuroscience $\quad 0270-6474 / 98 / 185529-08 \$ 05.00 / 0$ i.p.). Footshock reinstated cocaine seeking in both intact animals and animals with corticosterone replacement but not in adrenalectomized animals. The CRF receptor antagonist D-Phe $\mathrm{CRF}_{12-41}$ blocked footshock-induced reinstatement at all doses tested in both intact animals and animals with corticosterone replacement. Reinstatement by priming injections of cocaine was only minimally attenuated by adrenalectomy and by pretreatment with $\mathrm{D}-\mathrm{Phe} \mathrm{CRF}_{12-41}$. These data suggest that brain CRF plays a critical role in stress-induced, but only a modulatory role in cocaine-induced, reinstatement of cocaine seeking. Furthermore, the data show that although reinstatement of cocaine seeking by footshock stress requires minimal, basal, levels of corticosterone, stress-induced increases in corticosterone do not play a role in this effect.

Key words: adrenalectomy; corticosterone; CRF; cocaine self-administration; reinstatement; relapse; stress

injections of butyl-[2,5-dimethyl-7-(2,4,6-trimethylphenyl)-7Hpyrrolo [2,3-d] pyrimidin-4-yl]-ethylamine (Shaham et al., 1998), a nonpeptide corticotropin-releasing factor ${ }_{1}\left(\mathrm{CRF}_{1}\right)$ receptor antagonist (Chen et al., 1997). Thus it seems that in cocaine-trained animals, as in those trained to self-administer heroin (Shaham et al., 1997), CRF plays a significant role in stress-induced relapse. An important result from our previous studies on stress-induced relapse in heroin-trained animals was that manipulations of corticosterone were without effect, making it seem that the effects of CRF were independent of the hypothalamic-pituitary-adrenal (HPA) axis, acting directly in the brain to affect behavior (Menzaghi et al., 1993; Merlo Pich et al., 1995; Sarnyai et al., 1995).

In the case of cocaine, however, there is reason to think that the HPA axis plays an important role in the behavioral effects of cocaine. Cocaine, itself, is known to cause a stress-like rise in corticosterone that is mediated by CRF secretion (Sarnyai et al., 1992). When cocaine is administered intermittently over several days, this response to cocaine is maintained undiminished, as determined by levels of ACTH and corticosterone (Torres and Rivier, 1992). In behavioral studies, it has been found that cocaine-induced locomotion is reduced by adrenalectomy or by corticosterone synthesis inhibitors such as metyrapone (Marinelli et al., 1994, 1997). In addition, rats with higher basal levels of corticosterone are more likely to initiate cocaine and amphetamine self-administration (Piazza et al., 1991; Goeders and Guerin, 1996a; Piazza and LeMoal, 1996), and metyraponeinduced reductions of corticosterone attenuate the intake of cocaine during maintenance of self-administration (Piazza et al., 1994; Goeders and Guerin, 1996a). Finally, there is one report 
that within a narrow dose range intravenous injections of corticosterone can reinstate cocaine-taking behavior in intact rats (Deroche et al., 1997).

Because of their potential importance in relapse in animals self-administering cocaine, we studied, in the present experiment, the role of both CRF and corticosterone in stress- and cocaineinduced relapse to cocaine seeking. In all of the experiments, animals trained to self-administer cocaine intravenously were subsequently given several days of extinction training when saline was substituted for cocaine. After extinction, tests were given for reinstatement of cocaine seeking using brief exposure to footshock stress and priming (experimenter-delivered) injections of cocaine. To determine the separate roles of CRF and corticosterone on relapse induced by stress or cocaine, we studied the effects of central blockade of CRF receptors and manipulations of corticosterone using intact and adrenalectomized animals and animals adrenalectomized and given corticosterone replacement.

\section{MATERIALS AND METHODS}

\section{General methods}

\section{Subjects}

Male Long-Evans rats (375-450 gm; Charles River Laboratories, Wilmington, MA) served as subjects in these experiments. The animals were housed in a colony room for $2-3$ weeks before surgery and were allowed to recover for at least 2 weeks before being transferred to the operant chambers where they were housed permanently for the duration of the experiment on a reverse light/dark cycle (lights on from 9:00 P.M. to 9:00 A.M.), with food and water available ad libitum.

\section{Surgery}

Intravenous catheterization. Animals were prepared with intravenous silastic catheters (Dow Corning, Midland, MI) in the right jugular vein under sodium pentobarbital anesthesia $(65 \mathrm{mg} / \mathrm{kg}$, i.p.; MTC Pharmaceutical, Cambridge, Ontario, Canada). Just before surgery, animals were given atropine sulfate $(0.6 \mathrm{mg} / \mathrm{ml} ; 0.3 \mathrm{ml} /$ animal; MTC Pharmaceutical) and penicillin B (300,000 IU; $0.2 \mathrm{ml} /$ animal; Wyeth-Ayerst, Montreal, Quebec, Canada). The catheter was secured to the vein with silk sutures and was passed subcutaneously to the top of the skull where it exited into a connector (a modified 22 gauge cannula; Plastics One, Roanoke, VA) mounted to the skull with jeweler's screws and dental cement. A plastic blocker was placed over the opening of the connector during the recovery period. After animals had been transferred to the operant chambers, the catheters were flushed daily with $0.1 \mathrm{ml}$ of a saline-heparin solution (15 U/ml heparin; ICN Biochemicals, Montreal, Quebec, Canada).

Intraventricular cannulae. During surgery, each rat was also implanted with a 22 gauge guide cannula (Plastics One) from which the injector extended $1 \mathrm{~mm}$ to end in the left lateral ventricle. Stereotaxic coordinates used were as follows: $-1.0 \mathrm{~mm}$ from bregma, $+1.4 \mathrm{~mm}$ lateral from the midline, and $-3.7 \mathrm{~mm}$ from dura (Paxinos and Watson, 1986) measured from the tip of the injector. Cannulae placements were verified by giving each rat an intracerebroventricular infusion of angiotensin at $50 \mathrm{ng} / 2 \mathrm{ml}$ and by observing subsequent drinking behavior. Placements were considered to be accurate if a rat drank within 1 min of the infusion and sustained drinking over 2-3 min (Sakai et al., 1995).

Adrenalectomy. Bilateral adrenalectomies were performed rapidly under methoxyflurane anesthesia (Metofane; Jannsen Pharmaceuticals, Mississauga, Ontario, Canada) the day after the last day of training, 1 to $2 \mathrm{hr}$ after the start of the light cycle. Adrenalectomized animals were given physiological saline in their drinking bottles. In experiment 2 , animals given corticosterone replacement (CORT) had a pellet containing $50 \mathrm{mg}$ of corticosterone and $50 \mathrm{mg}$ of cholesterol implanted subcutaneously at the time of surgery (Meyer et al., 1979), and corticosterone 21-hemisuccinate, in a concentration of $50 \mu \mathrm{g} / \mathrm{ml}$, was added to the drinking water (CORT/PW) (Marinelli et al., 1994). In experiment 3, only pellets were used to replace corticosterone (CORT/P). Animals in the sham group (SHAM) were exposed to the same surgical manipulations as the adrenalectomized groups (ADX) except that the adrenals were not removed and they were not given physiological saline to drink.

\section{Measurement of plasma corticosterone}

At the end of the experiment, tail blood was collected in heparinized tubes immediately before and after exposure to 10 min of footshock. A radioimmunoassay for plasma corticosterone was conducted to verify that the adrenalectomies were complete. The assays were conducted with the help of Claire-Dominique Walker, Douglas Hospital Research Center, McGill University, using a kit from ICN Biochemicals (Medicorp, Montreal, Quebec, Canada) and ${ }^{125} \mathrm{I}$-corticosterone as the tracer. The limit of detection was $0.31 \mu \mathrm{g} / \mathrm{dl}$.

\section{Apparatus}

The operant chambers had two levers located $9 \mathrm{~cm}$ above the floor; one lever (an active, retractable lever; Med Associates, Lafayette, IN) activated the infusion pump (Razel Scientific, Stamford, CT), and the other lever (an inactive, stationary lever) did not activate the infusion pump, but all presses were recorded. Drug or saline was infused at a volume of $0.13 \mathrm{ml}$ during a $20 \mathrm{sec}$ period. During the inf usion, a light located above the active lever was lit for $20 \mathrm{sec}$. Lever presses during those $20 \mathrm{sec}$ were recorded but did not lead to further infusions (time-out responses). Throughout the experiment, each session began by the introduction of the retractable lever and the illumination of the white light above the lever (for $30 \mathrm{sec}$ ) and of a red house light (for the entire session). The grid floors of the chambers were connected to electric shock generators (Grason-Stadler, West Concord, MA, or Med Associates).

\section{Drugs}

Cocaine $\mathrm{HCl}$ was obtained from $\mathrm{BDH}$ Chemicals, Poole, UK, and was dissolved in physiological saline. D-Phe $\mathrm{CRF}_{12-41}(0.1,0.3$, and 1.0 $\mu \mathrm{g} / \mathrm{rat})$, generously supplied to us by Jean Rivier, Salk Institute, La Jolla, $\mathrm{CA}$, was dissolved in physiological saline.

\section{Procedures}

Experiment 1: effects of D-Phe CRF ${ }_{12-41}$ on footshock- and cocaine-induced reinstatement of cocaine seeking in normal intact animals

In this experiment, the effects of blockade of CRF receptors on reinstatement induced by footshock and cocaine were studied using the CRF receptor antagonist D-Phe $\mathrm{CRF}_{12-41}$. D-Phe $\mathrm{CRF}_{12-41}$ was inf used intracerebroventricularly in normal intact animals trained to self-administer cocaine.

The experiment was run in three phases: self-administration training, extinction, and testing for reinstatement. Each day, just before lights were turned off, rats were weighed, and the catheters were flushed with heparin. During the training and testing phases, animals were allowed to self-administer during one $3 \mathrm{hr}$ session each day ( $7 \mathrm{~d} /$ week), 3-4 hr after lights were turned off. During extinction, animals received one or two 3 hr sessions/day; when more than one session was given in a day, the sessions were separated by $2 \mathrm{hr}$.

Training. Rats were trained to self-administer cocaine $\mathrm{HCl}(1.0 \mathrm{mg} /$ $\mathrm{kg}$ /infusion, i.v.) on a schedule of one response to one reinforcement Rats were given between 10 and 14 training days; training conditions continued until stable responding ( $20 \%$ or less variation from day to day) was maintained over at least 8 consecutive days.

Extinction. During extinction, conditions remained the same as those in training except that saline was substituted for cocaine. These extinction conditions remained in place until rats reached a baseline criterion level of responding of 10 or fewer responses in a $3 \mathrm{hr}$ session. At this point, a few additional extinction sessions were given before intracerebroventricular infusions of vehicle and intraperitoneal injections of saline were administered until animals habituated to the injection procedures and did not exceed 10 responses (saline infusions + time-out responses) in a $3 \mathrm{hr}$ session. Animals were given a minimum of $5 \mathrm{~d}$ of extinction sessions; the number of days to reach criterion ranged from 5 to 14 .

Tests for reinstatement. Animals were assigned to one of four pretreatment conditions: vehicle $(n=10)$ or $0.1 \mu \mathrm{g}(n=9), 0.3 \mu \mathrm{g}(n=11)$, or $1.0 \mu \mathrm{g}(n=10)$ of D-Phe $\mathrm{CRF}_{12-41}$ intracerebroventricularly. Infusions were given $40 \mathrm{~min}$ before access to the lever during the tests for reinstatement (30 min before onset of footshock and $35 \mathrm{~min}$ before priming injections). The time interval between infusions and exposure to footshock was chosen on the basis of the work of Menzaghi et al. (1994). Animals in each pretreatment condition were tested on separate days after a priming injection of saline (physiological saline, $1.0 \mathrm{ml} / \mathrm{kg}$, i.p.; 5 min before the start of the session) and a priming injection of cocaine (20 
$\mathrm{mg} / \mathrm{kg}$, i.p.; 5 min before the start of the session) and after exposure to intermittent footshock ( $10 \mathrm{~min} ; 0.5 \mathrm{~mA}$; $0.5 \mathrm{sec}$ on; mean off period of 40 sec; immediately before the start of the session). The dose of cocaine was chosen on the basis of a pilot study and on the basis of a previous study in which it was found to reinstate drug seeking reliably in rats trained to self-administer cocaine (Worley et al., 1994). At this dose, reinstatement of responding does not occur immediately after the injection, but it can be shown (see Fig. 1, bottom) that responding occurs primarily in the first hour, with some responding in the second. The footshock parameters are the same as those used in a previous study of relapse to cocaine seeking from this laboratory (Erb et al., 1996). All rats received the saline test first; the order of the cocaine and footshock tests was counterbalanced over consecutive days. During the tests for reinstatement, extinction conditions remained; lever pressing resulted in intravenous infusions of saline.

\section{Experiment 2: effects of adrenalectomy with and without corticosterone replacement on cocaine- and footshock-induced reinstatement of cocaine seeking}

In experiment 2, the possible role of corticosterone in reinstatement induced by footshock and cocaine was studied using adrenalectomy with and without corticosterone replacement. Animals were trained to selfadminister cocaine and were adrenalectomized before the beginning of the extinction phase of the experiment.

The experiment was run in three phases: self-administration training, extinction, and testing for reinstatement. On the day after the final training session, animals were either adrenalectomized (ADX; $n=11$ ), adrenalectomized and given corticosterone replacement (CORT/PW; $n=9)$, or given a sham surgery (SHAM; $n=10)$. The animals were allowed $36 \mathrm{hr}$ to recover from surgery before the start of the first extinction session. Extinction proceeded under conditions similar to those of experiment 1 . In experiment 2 , however, after rats responded fewer than 15 times in a given $3 \mathrm{hr}$ session, intraperitoneal injections of saline were given before each session to habituate the animals to injections and handling. The number of days of extinction to criterion ranged from 5 to 14 . As in experiment 1 , when an animal reached the criterion level of responding of 10 or fewer responses (saline inf usions + time-out responses) on the active lever in a $3 \mathrm{hr}$ session, testing for reinstatement began for that animal. All animals were tested after priming injections of saline and cocaine and after exposure to footshock. Animals received two cocaine tests and two footshock tests. As in experiment 1, the saline test was given first, followed by a cocaine and a footshock test on alternate days. Some animals received a cocaine test first, and others received a footshock test first. The parameters of the various test conditions were the same as those used in experiment 1.

Experiment 3: effects of D-Phe $C R F_{12-41}$ on footshock-induced reinstatement of cocaine seeking in adrenalectomized animals with corticosterone replacement

Experiment 3 was conducted to determine whether intracerebroventricular infusions of the CRF receptor antagonist D-Phe $\mathrm{CRF}_{12-41}$ could alter footshock-induced reinstatement of cocaine seeking via its direct actions on the CNS. To this end, the effects of intracerebroventricular inf usions were studied in adrenalectomized animals given corticosterone pellets sufficient to maintain steady plasma levels of corticosterone.

The training and extinction phases were conducted as described above. On the day after the final training session, animals were adrenalectomized and received corticosterone replacement pellets (CORT/P; $n=$ 5). Extinction sessions were performed as described in experiment 1 and ranged from 6 to $10 \mathrm{~d}$ to criterion. In the reinstatement test phase, all animals were tested in both footshock and no-footshock conditions after pretreatment with both D-Phe $\mathrm{CRF}_{12-41}(1.0 \mu \mathrm{g}$, i.c.v. $)$ and vehicle intracerebroventricularly. Thus, animals received a total of four tests for reinstatement: D-Phe $\mathrm{CRF}_{12-41}+$ no footshock; vehicle + no footshock; D-Phe $\mathrm{CRF}_{12-41}+$ footshock; and vehicle + footshock. The same footshock parameters used for experiments 1 and 2 were used. Three animals received D-Phe $\mathrm{CRF}_{12-41}$ pretreatment first, and two received vehicle pretreatment first; within each pretreatment condition, the no-footshock test preceded the footshock test. The timing of the intracerebroventricular infusions of D-Phe $\mathrm{CRF}_{12-41}$ was as described in experiment 1.

\section{Statistical analyses}

The dependent measures for the tests for reinstatement were numbers of responses on the active and inactive levers. Separate analyses were conducted for responding on each lever. In all experiments, the test condition (saline, cocaine, and footshock [experiments 1 and 2]; no footshock and footshock [Experiment 3]) was the within-subjects factor. The dose of D-Phe $\mathrm{CRF}_{12-41}(0,0.1,0.3$, and $1.0 \mu \mathrm{g})$ and the surgery condition (ADX, CORT, and SHAM) served as the between-subjects factors in experiments 1 and 2, respectively; in experiment 3, the pretreatment condition (vehicle and D-Phe $\mathrm{CRF}_{12-41}$ ) was a second withinsubjects factor. All behavioral data are presented as mean \pm SEM. Because of the very large differences in variability in the number of responses made in the different tests for reinstatement, the nonparametric statistics for related (Friedman and Wilcoxon) and nonrelated (Kruskal-Wallis and Mann-Whitney) samples were used.

\section{RESULTS}

Experiment 1: effects of D-Phe $\mathrm{CRF}_{12-41}$ on footshockand cocaine-induced reinstatement of cocaine seeking in normal intact animals

\section{Training and extinction phases}

During training, rats self-administered four to six infusions per hour of cocaine HCL at $1.0 \mathrm{mg} / \mathrm{kg}$ per infusion. The mean ( \pm SEM) numbers of infusions made on the last $2 \mathrm{~d}$ of training were $17.90( \pm 1.21)$ and $18.18( \pm 1.18)$ inf usions per $3 \mathrm{hr}$ session. The mean $( \pm$ SEM) numbers of responses (saline infusions + timeout responses) made on the active lever on the first $2 \mathrm{~d}$ of extinction were 40.95 ( \pm 6.20) and 43.77 ( \pm 6.99$)$. By the last extinction session, all animals had reached the criterion of 10 or fewer responses.

\section{Reinstatement test phase}

Figure 1 (top) shows the mean number of responses (saline inf usions + time-out responses) made on the active lever for each of the D-Phe $\mathrm{CRF}_{12-41}$-dose groups under the three test conditions: Saline, Footshock, and Cocaine. Both footshock stress and priming injections of cocaine reinstated cocaine seeking. Administration of the CRF antagonist D-Phe $\mathrm{CRF}_{12-41}$ blocked the footshock effect at all doses tested [Kruskal-Wallis, $X^{2}(3)=$ 14.03; $p<0.01$; Fig. 1, Footshock]; furthermore, the response to footshock under each of the doses did not differ from the response to saline. Although the effect of dose on reinstatement by the priming injection of cocaine was statistically significant $\left[X^{2}(3)=\right.$ 7.65; $p=0.05]$, inspection of Figure 1, Cocaine, shows that reinstatement was mildly attenuated and only at the lowest $(0.1$ $\mu \mathrm{g})$ and highest $(1.0 \mu \mathrm{g})$ doses but not at the intermediate dose. In all cases, the response to cocaine was significantly greater than the response to saline.

Figure 1 (bottom) shows the mean number of responses made on the active lever at each hour of the tests for reinstatement under the various conditions. Kruskal-Wallis tests conducted for dose $\left(0,0.1,0.3\right.$, and $1.0 \mu \mathrm{g}$ of $\left.\mathrm{D}-\mathrm{Phe} \mathrm{CRF}_{12-41}\right)$ in each hour of testing revealed that the only significant dose effect was found in hour 1 of the footshock test.

In this and subsequent experiments, responding on the inactive lever was minimal (means ranging from 0.62 to 5.31), and in no case was there a significant effect of treatment on the number of responses on this lever.

\section{Experiment 2: effects of adrenalectomy and corticosterone replacement on footshock- and cocaine-induced reinstatement of cocaine seeking} Training phase

Rats self-administered six to seven infusions per hour, $1.0 \mathrm{mg} / \mathrm{kg}$ per infusion, of cocaine $\mathrm{HCl}$. The mean ( \pm SEM) numbers of inf usions made on the last $2 \mathrm{~d}$ of training were $20.9( \pm 0.96)$ and 20.5 ( \pm 1.08 ) infusions in each $3 \mathrm{hr}$ session. 

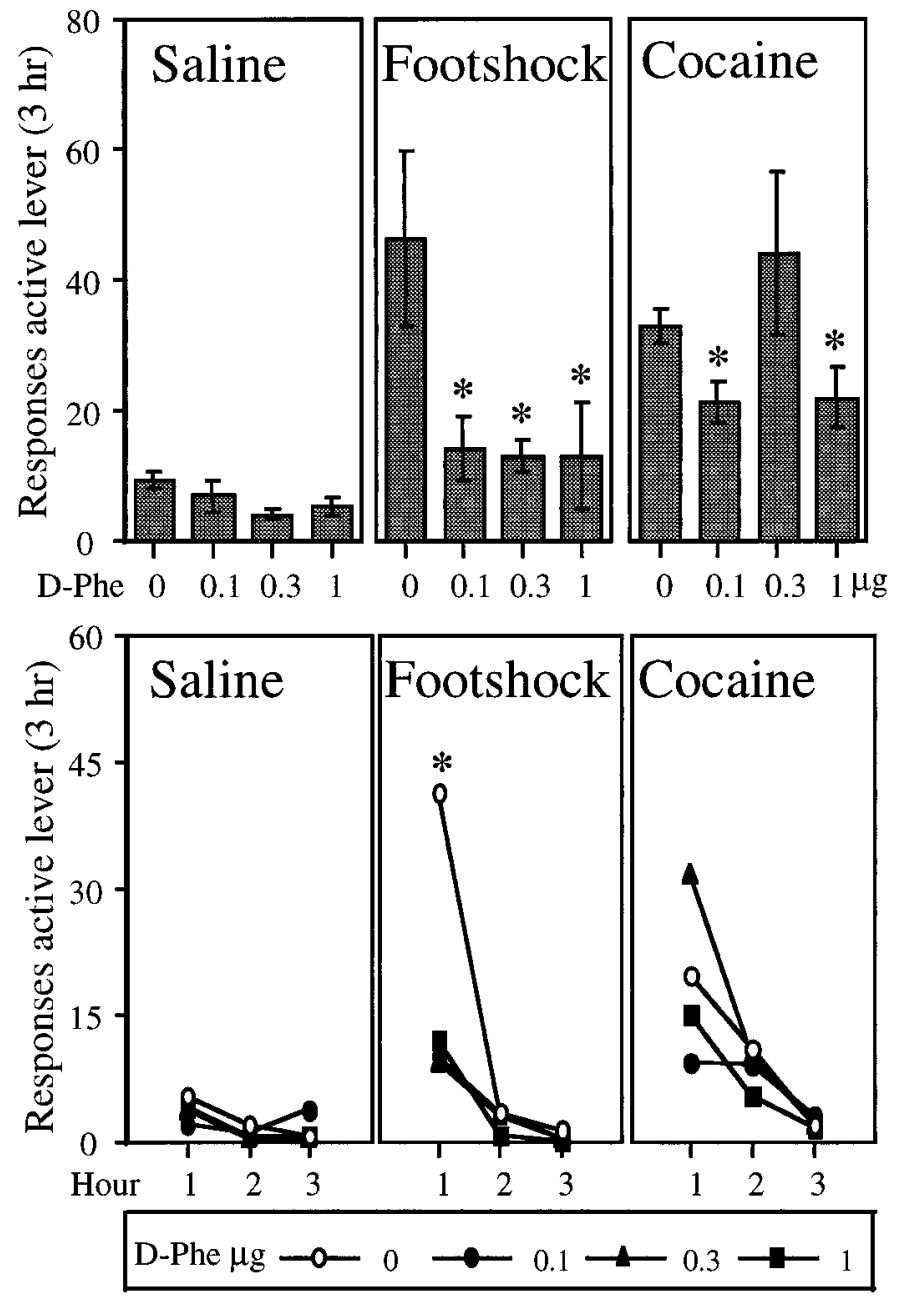

Figure 1. Top, The effect of the CRF receptor antagonist D-Phe $\mathrm{CRF}_{12-41}(D-P h e)$ on the mean $\pm \mathrm{SEM}$ total number of responses (saline infusions + time-out responses) on the active lever in $3 \mathrm{hr}$ tests for reinstatement after Saline (physiological saline, $1.0 \mathrm{ml} / \mathrm{kg}$, i.p.; $5 \mathrm{~min}$ before the start of the session), Footshock (intermittent footshock, 10 min; $0.5 \mathrm{~mA} ; 0.5 \mathrm{sec}$ on; mean off period of $40 \mathrm{sec}$; immediately before the start of the session), and Cocaine ( $20 \mathrm{mg} / \mathrm{kg}$, i.p.; $5 \mathrm{~min}$ before the start of the session). Groups of intact animals were tested in each reinstatement test condition under one dose of $D$-Phe given intracerebroventricularly $(0 \mu \mathrm{g}$, $n=10 ; 0.1 \mu \mathrm{g}, n=9 ; 0.3 \mu \mathrm{g}, n=11$; and $1.0 \mu \mathrm{g}, n=10)$. The asterisk indicates a difference from the $0 \mu \mathrm{g}$ dose of $D$-Phe in the same test condition; Mann-Whitney $(p<0.05)$. Bottom, The effect of $D$-Phe on the mean number of responses (saline infusions + time-out responses) on the active lever in each hour of each of the $3 \mathrm{hr}$ tests for reinstatement. The asterisk indicates a difference from all doses of D-Phe in the Footshock test condition in hour 1; Mann-Whitney $(p<0.05)$.

\section{Extinction phase}

Because of the possible effects of adrenalectomy and corticosterone replacement on responding during extinction, data for the three groups (SHAM, ADX, and CORT/PW) were subjected to one-way ANOVAs for the number of days to criterion (mean \pm SEM, $7.78 \pm 0.86 ; 6.73 \pm 0.36$; and $8.17 \pm 0.4$, respectively) and for the number of responses made on the first $2 \mathrm{~d}$ of extinction (SHAM, $46.11 \pm 10.88$ and $23.11 \pm 4.17$; ADX, $29.36 \pm 4.63$ and $35.09 \pm 7.68$; and CORT/PW, $53.00 \pm 16.78$ and $28.50 \pm 10.71$ ). No significant differences between groups were found $\left[X^{2}(2)=\right.$ $1.79 ; p=0.41]$. By the last extinction session, all animals had reached the criterion of 10 or fewer responses.
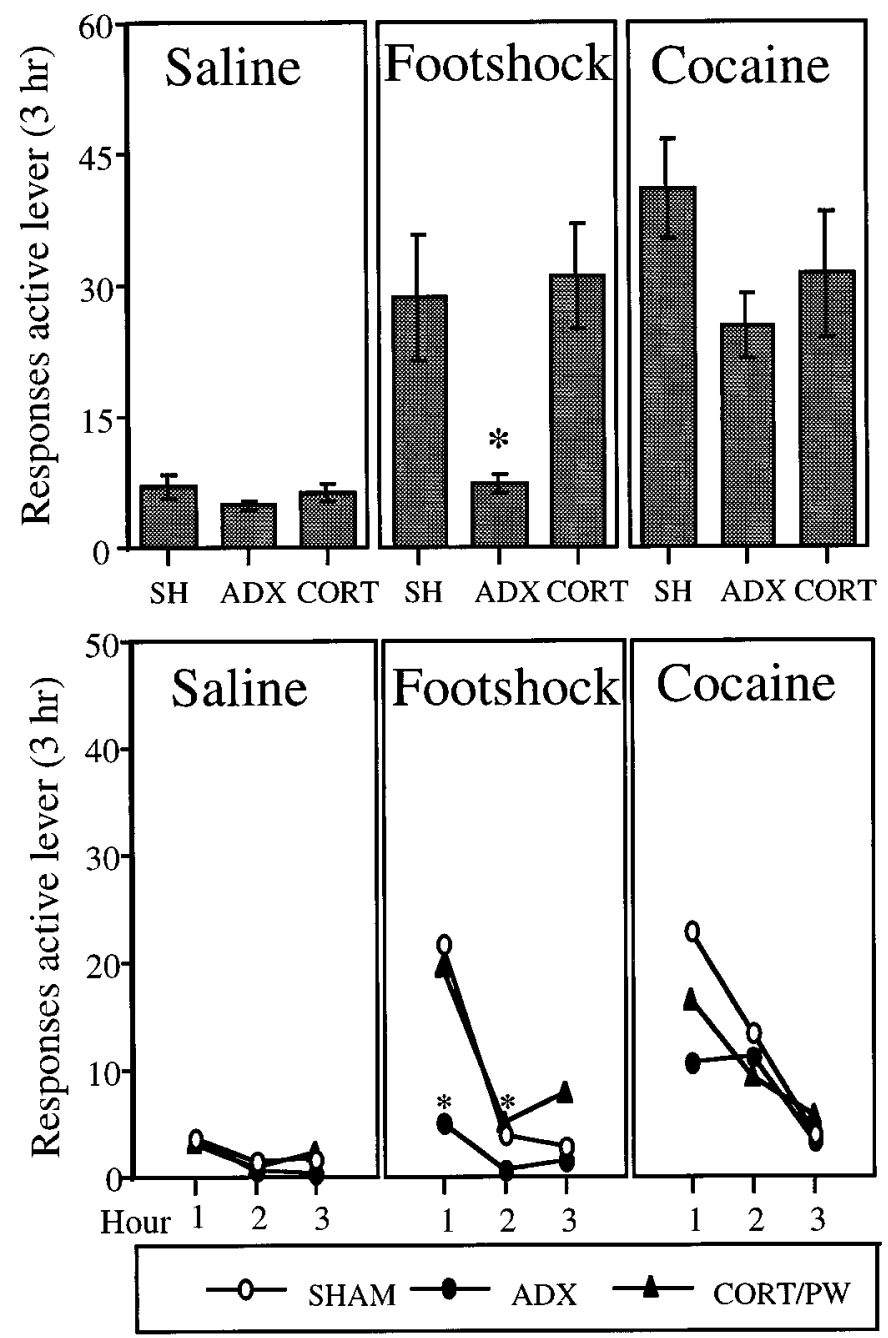

Figure 2. Top, The effect of adrenalectomy (ADX; $n=11)$ and corticosterone replacement (CORT/PW; $n=9)$ and sham surgery (SHAM; $n=$ 10 ) on the mean \pm SEM total number of responses (saline infusions + time-out responses) on the active lever in $3 \mathrm{hr}$ tests for reinstatement after Saline (physiological saline, $1.0 \mathrm{ml} / \mathrm{kg}$, i.p.; $5 \mathrm{~min}$ before the start of the session), Footshock (intermittent footshock, $10 \mathrm{~min} ; 0.5 \mathrm{~mA} ; 0.5 \mathrm{sec}$ on; mean off period of $40 \mathrm{sec}$; immediately before the start of the session), and Cocaine $(20 \mathrm{mg} / \mathrm{kg}$, i.p.; $5 \mathrm{~min}$ before the start of the session). Animals in each group (SHAM, ADX, and CORT/PW) were tested under all three test conditions. The asterisk indicates a difference from SHAM and CORT/PW in the Footshock test condition; Mann-Whitney $(p<0.05)$. Bottom, The effect of adrenalectomy (ADX; $n=11)$ and corticosterone replacement (CORT/PW; $n=9)$ and sham surgery (SHAM; $n=10)$ on the mean number of responses (saline infusions + time-out responses) on the active lever in each hour of the $3 \mathrm{hr}$ tests for reinstatement. The asterisk indicates a difference from SHAM and CORT/PW in the Footshock test condition; Mann-Whitney $(p<0.05)$.

\section{Reinstatement test phase}

Figure 2 (top) shows the number of responses (mean of two tests) on the active lever (saline infusions + time-out responses) for SHAM, ADX, and CORT/PW animals under the Saline, Footshock, and Cocaine test conditions. Both footshock stress and priming injections of cocaine reinstated cocaine seeking in SHAM and CORT/PW animals. Footshock stress, however, did not reinstate cocaine seeking in ADX animals. Kruskal-Wallis analyses for the factor of group (SHAM, ADX, and CORT/PW) performed for each of the test conditions, Saline, Footshock, and 
Cocaine, revealed a significant effect of group in the Footshock test condition $\left[X^{2}(2)=10.53 ; p<0.05\right]$; the effect of group was not significant in either the Cocaine $\left[X^{2}(2)=3.67 ; p=0.16\right]$ or Saline $\left[X^{2}(2)=2.08 ; p=0.35\right]$ test conditions.

Figure 2 (bottom) shows the mean number of responses made on the active lever for each group at each hour of testing and under the various test conditions. The patterns of responding over the $3 \mathrm{hr}$ test sessions were very similar to those observed in experiment 1. In the Footshock test condition, most of the responding was in the first hour; in the Cocaine test condition, responding occurred in both the first and second hours. KruskalWallis analyses for the factor of group (SHAM, ADX, and CORT/PW) performed for each of the test conditions at each hour of testing revealed significant effects in both hour $1\left[X^{2}(2)=\right.$ 7.64; $p<0.03]$ and hour $2\left[X^{2}(2)=9.39 ; p<0.03\right]$ of the Footshock test. Experiment 3: effects of D-Phe CRF ${ }_{12-41}$ on footshock-induced reinstatement of cocaine seeking in adrenalectomized animals given corticosterone replacement

\section{Training and extinction phases}

Rats self-administered four to six infusions per hour, $1.0 \mathrm{mg} / \mathrm{kg}$ per infusion, of cocaine $\mathrm{HCl}$. The mean ( \pm SEM) numbers of inf usions made on the last $2 \mathrm{~d}$ of training were, respectively, 16.4 ( \pm 3.2$)$ and $17.0( \pm 3.1)$ infusions in each $3 \mathrm{hr}$ session. The mean ( \pm SEM) numbers of responses (saline infusions + time-out responses) made on the active lever on the first $2 \mathrm{~d}$ of extinction were $32.80 \pm 5.99$ and $25.40 \pm 2.77$. By the last extinction session, all animals had reached the criterion of 10 or fewer responses.

\section{Reinstatement test phase}

Figure 3 shows the mean number of responses made on the active lever (saline infusions + time-out responses) by CORT/P animals during No-Footshock and Footshock test sessions after pretreatment with vehicle or $\mathrm{D}-\mathrm{Phe} \mathrm{CRF}_{12-41}$. It can be seen that pretreatment with $\mathrm{D}-\mathrm{Phe} \mathrm{CRF}_{12-41}$ greatly attenuated footshockinduced reinstatement. Although in both conditions there was an increase in responding on the active lever after footshock (Wilcoxon, $p<0.05$ ), the level of responding in response to footshock after vehicle was significantly greater than that after D-Phe $\mathrm{CRF}_{12-41}$ pretreatment (Wilcoxon, $p<0.05$ ). There was no difference in responding between pretreatment conditions in the absence of footshock $(p=0.22)$. As in the other two experiments, the greatest number of responses after footshock occurred in the first hour of the sessions. It can be noted that the level of responding in the vehicle condition in this experiment was higher than that in similarly treated animals in experiment 2. This difference probably reflects the fact that there were fewer animals in experiment 3 and a higher degree of variability.

\section{Verification of adrenalectomy and corticosterone replacement}

The concentration $(\mu \mathrm{g} / \mathrm{dl})$ of corticosterone in plasma samples collected from rats before and after footshock (10 min; intermittent; $0.5 \mathrm{~mA}$ ) was determined for the different groups of experiments 2 and 3. Two animals showing significant increases in corticosterone in response to stress, indicative of incomplete removal of the adrenals, were excluded from the study. Plasma corticosterone concentrations from animals that received sham surgery (SHAM), adrenalectomy (ADX), or adrenalectomy with corticosterone replacement (CORT/PW and CORT/P) are shown in Table 1. The number of animals in each of the two CORT groups is reduced by one because of the loss of a single

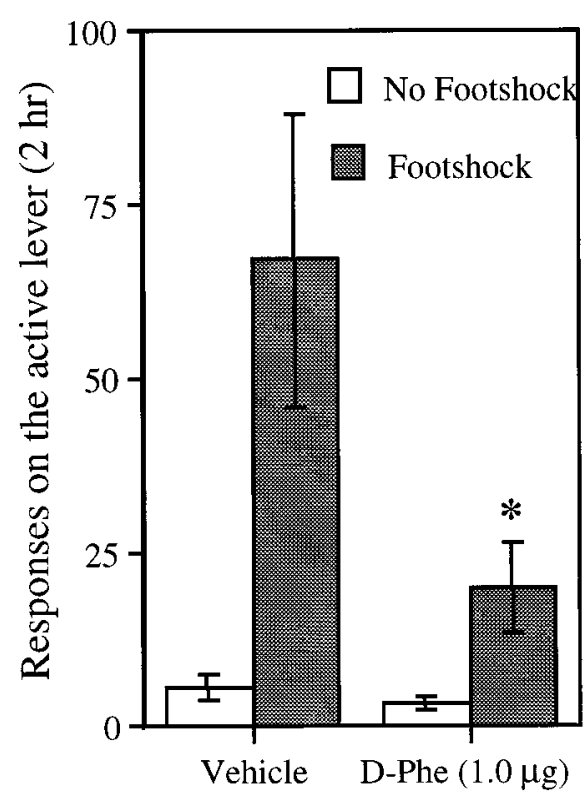

Pretreatment

Figure 3. Effect of $D$-Phe in adrenalectomized animals with corticosterone replacement $(\mathrm{CORT} / \mathrm{P} ; n=5)$ on the mean \pm SEM total number of responses on the active lever (saline infusions + time-out responses) in 2 hr tests for reinstatement after No Footshock and Footshock (intermittent footshock, $10 \mathrm{~min} ; 0.5 \mathrm{~mA} ; 0.5 \mathrm{sec}$ on; mean off period of $40 \mathrm{sec}$; immediately before the start of the session). All animals were tested after pretreatment with vehicle and with $D$-Phe given intracerebroventricularly 40 min before the test in both the No Footshock and Footshock test conditions. The number of responses in Footshock tests was greater than that in the No Footshock tests with both vehicle and $D$-Phe (Wilcoxon, $p<$ $0.05)$. The asterisk indicates a difference from vehicle in the Footshock test condition (Wilcoxon, $p<0.05$ ).

Table 1. Plasma corticosterone levels $(\mu \mathrm{g} / \mathrm{dl})$ immediately before and after 10 min of intermittent footshock stress

\begin{tabular}{lrr} 
Group & \multicolumn{1}{l}{ Before } & \multicolumn{1}{l}{ After } \\
\hline SHAM $(n=10$; experiment 2$)$ & $12.12 \pm 1.45$ & $16.38 \pm 1.44$ \\
ADX $(n=11$; experiment 2$)$ & $0.73 \pm 0.38$ & $0.82 \pm 0.51$ \\
CORT/PW $(n=8$; experiment 2$)$ & $9.27 \pm 1.25$ & $8.08 \pm 1.40$ \\
CORT/P $(n=4$; experiment 3$)$ & $6.92 \pm 2.78$ & $6.33 \pm 2.41$ \\
\hline
\end{tabular}

"before" or "after" sample. A two-way ANOVA for group by time (before and after stress) showed that there was a significant group effect $\left[F_{(3,29)}=36.17 ; p<0.001\right]$; SHAM animals had higher basal and stress levels of corticosterone than did all other groups. The levels in ADX animals were minimal and significantly different from those in all other groups. The significant group-bytime interaction $\left[F_{(3,29)}=3.0 ; p<0.05\right]$ reflects the fact that only in the SHAM group was there an increase in levels in response to stress.

\section{DISCUSSION}

\section{Stress-induced relapse}

The primary finding from the present experiments is that the potent CRF receptor antagonist D-Phe $\mathrm{CRF}_{12-41}$ suppressed footshock-induced relapse to cocaine seeking in intact animals and in adrenalectomized animals given corticosterone replacement. These data suggest that CRF can act directly in the brain, 
independent of its effects on the HPA axis, to mediate the effects of footshock on relapse. These effects of the CRF receptor antagonist on stress-induced reinstatement of cocaine seeking extend those from our previous studies with heroin-trained rats. We found that the peptide CRF receptor antagonist $\alpha$-helical CRF and the nonpeptide CRF antagonist CP-154,526 attenuated stress-induced reinstatement of heroin seeking (Shaham et al., 1997, 1998). It is important to note, however, that pharmacological blockade of the CRF system seems to exert a stronger effect on stress-induced reinstatement in cocaine-trained rats compared with heroin-trained rats. In heroin-trained rats, antagonism of the CRF system decreased footshock-induced reinstatement by $\sim 50 \%$; responding, however, was significantly above the no-stress baseline levels (Shaham et al., 1997, 1998). In contrast, in cocainetrained rats, both peptide (present experiment) and nonpeptide (Shaham et al., 1998) CRF receptor antagonists completely blocked stress-induced reinstatement. Thus, it seems that, for reasons that are yet to be elucidated, the CRF system is more critically involved in stress-induced reinstatement in subjects previously exposed to cocaine.

A second finding from the present experiments is that footshock did not induce reinstatement of cocaine seeking in adrenalectomized animals. This lack of response was reversed when adrenalectomized animals were given basal levels of corticosterone replacement. These findings indicate that although stressinduced reinstatement can occur in the absence of a stressinduced rise in corticosterone, some minimal level of corticosterone is necessary for the footshock stressor to induce reinstatement in cocaine-trained animals. The data are different from those obtained in our previous work with heroin-trained rats. We found that adrenalectomy did not attenuate stressinduced reinstatement in heroin-trained rats (Shaham et al., 1997).

The differential effect of adrenalectomy on stress-induced reinstatement in cocaine- and heroin-trained animals may arise from the different effects of repeated exposure to these drugs on the response of the HPA axis. There is evidence that the cocaineinduced rise in corticosterone and ACTH does not diminish in animals given repeated intermittent injections of cocaine (Torres and Rivier, 1992). In the case of opioid agonists, however, acute injections increase plasma corticosterone and ACTH levels, whereas repeated exposure leads to a complete tolerance of these effects (Pechnick, 1993). For example, Buckingham and Cooper (1984) showed that acute injection of a moderate dose of morphine (20 mg/kg, i.p.) increased plasma levels of ACTH and corticosterone. However, after nine daily injections, plasma levels of the hormones were significantly below control levels. This difference in the effects of opioid agonists and cocaine on the HPA axis could have consequences of relevance for an understanding of the differential effect of adrenalectomy in cocaineand heroin-trained rats.

One possible consequence is that the self-administration of heroin and cocaine becomes differentially dependent on the presence of corticosterone during training and maintenance of the behavior. That is, responding becomes differentially statedependent. In the case of cocaine, responding for the drug is normally accompanied by increases in corticosterone, and thus some minimal level of corticosterone may be required to maintain responding, especially in the absence of cocaine and after extinction of the drug-related cues. In contrast, in the case of heroin, if after repeated drug self-administration levels of corticosterone are suppressed (a likely outcome in rats that self-administered a high unit dose of heroin, $0.1 \mathrm{mg} / \mathrm{kg} /$ infusion, for $9 \mathrm{hr} /$ day), then adrenalectomy might have minimal consequences on responding during tests for reinstatement.

Another possible explanation for the effect of adrenalectomy on stress-induced reinstatement in cocaine-trained rats might arise from the effect of adrenalectomy on the functioning of the extrahypothalamic CRF system. Recent studies suggest that glucocorticoids regulate CRF expression in the amygdala and the locus coeruleus. These brain areas are involved in the stress response and in the behavioral effects of CRF (Dunn and Berridge, 1990; Valentino et al., 1993; Gray and Bingaman, 1996) and might also be involved in the effect of CRF in stress-induced relapse. Pavcovich and Valentino (1997) have reported that, although adrenalectomy increases the spontaneous discharge rate of locus coeruleus neurons, the dose-effect curve for CRF increases in neuronal firing is shifted to the right. Makino et al. (1994a,b) reported that adrenalectomy modestly decreased, whereas high doses of corticosterone increased, CRF mRNA in the central nucleus of the amygdala. Finally and perhaps most relevant to the present set of data is the observation that in adrenalectomized rats administration of corticosterone results in a dose-dependent increase in the expression of CRF mRNA in the central nucleus of the amygdala (Swanson and Simmon, 1989). These studies suggest that CRF functioning in the locus coeruleus and in the amygdala may be attenuated in adrenalectomized rats. It is possible, therefore, that in adrenalectomized animals, the CRF response to footshock in these brain areas is reduced, resulting in decreased responsiveness to the stressor in tests for reinstatement. One weakness of this latter argument is that adrenalectomy failed to attenuate stress-induced reinstatement in heroin-trained rats (Shaham et al., 1997). It should be noted, however, that, as mentioned above, the effect of blockade of CRF receptors on stress-induced reinstatement is considerably greater in cocaine-trained rats than in heroin-trained rats.

\section{Cocaine-induced relapse}

In this series of experiments, we also assessed the role of CRF and corticosterone in reinstatement induced by priming injections of cocaine. In experiment 1 , it was found that pretreatment with the CRF antagonist had some effect on cocaine-induced reinstatement; responding was mildly attenuated both at the lowest $(0.1 \mu \mathrm{g})$ and the highest $(1.0 \mu \mathrm{g})$ doses of D-Phe $\mathrm{CRF}_{12-41}$ tested but, unaccountably, not at the intermediate dose. These findings suggest that although the activation of CRF receptors is not critical for cocaine-induced relapse, CRF plays a modulatory role in reinstatement by cocaine, possibly via its interactions with the midbrain dopamine (DA) system known to be involved in cocaine-induced reinstatement. Activation of this system has been shown to mediate reinstatement by both stimulant and opioid drugs (Stewart, 1984; Stewart and Vezina, 1988), and there is evidence that CRF has effects on this system. For example, CRF has been shown to induce behavioral sensitization to D-amphetamine (Cador et al., 1993) and to increase DA use in terminal regions of the mesolimbic DA system (Lavicky and Dunn, 1993). However, it has been found that maintenance of cocaine self-administration is not affected by blockade of CRF receptors (Ahmed et al., 1996).

Another important finding from the present study is that corticosterone appeared to be only minimally involved in reinstatement induced by priming injections of cocaine. Adrenalectomy did not block reinstatement by the priming injections of cocaine. Although there was a modest attenuation of responding in adre- 
nalectomized animals, the number of responses was well above that seen after the priming injections of saline (Fig. 2). Furthermore, the fact that corticosterone replacement had little effect in adrenalectomized animals suggests that, in contrast to footshockinduced reinstatement, minimal levels of corticosterone are not required for cocaine-induced reinstatement.

It is somewhat surprising that adrenalectomy had little effect on cocaine-induced reinstatement, given that adrenalectomy and administration of synthesis inhibitors of corticosterone have been shown to reduce the reinforcing effects of cocaine and cocaineinduced locomotion. Both adrenalectomy and synthesis inhibitors of corticosterone interfere with the initiation and maintenance of cocaine self-administration (Piazza et al., 1994; Goeders and Guerin, 1996a,b; Deroche et al., 1997) and reduce the acute psychomotor effects of cocaine (Marinelli et al., 1997). Piazza and colleagues have argued on the basis of these data that corticosterone tonically enhances dopaminergic transmission in the midbrain dopamine system (Piazza et al., 1996). It may well be, therefore, that the effects of adrenalectomy on cocaine-induced behaviors will be less obvious at doses of the drug that are sufficiently high to overcome any effect of reduced dopaminergic tone. Thus, it is possible that adrenalectomy would attenuate reinstatement by lower doses of cocaine than that used in the present experiments.

\section{Implications for the neurobiology of relapse}

The differential effect of the CRF antagonist on reinstatement induced by stress and by priming injections of cocaine lends support to the view that the neural and hormonal mechanisms underlying stress-induced reinstatement are not identical to those underlying drug-induced reinstatement (Shaham et al., 1997). In our experiments, stress-induced reinstatement was completely blocked (cocaine-trained rats) or attenuated (heroin-trained rats) by CRF antagonists. In these experiments, however, antagonism of CRF receptors had minimal effects on reinstatement induced by priming injections of drugs. As mentioned before, previous work has identified the mesolimbic DA system as the primary site for reinstatement induced by priming injections of heroin and cocaine (Stewart, 1984; Stewart and Vezina, 1988; Wise et al., 1990; Self et al., 1996, 1998; Shaham and Stewart, 1996). Our recent studies suggest that $\mathrm{CRF}$ plays a major role in relapse to heroin and cocaine induced by exposure to stress. Our data also provide conclusive evidence that CRF exerts its effects on stressinduced relapse by its actions on extrahypothalamic brain sites. These data, together with that from recent studies indicating an important role of extrahypothalamic CRF in the aversive effects of drug withdrawal (Menzaghi et al., 1994; Heinrichs et al., 1995; Sarnyai et al., 1995; Koob, 1996), indicate that alterations in the CRF system in the brain may play a major role in compulsive drug use.

\section{REFERENCES}

Ahmed SH, Koob GF (1997) Cocaine- but not food-seeking behavior is reinstated by stress after extinction. Psychopharmacology (Berl) 132:289-295.

Ahmed S, Epping-Jordan M, Griffin P, Markou S, Heinrick S, De Souza E, Rivier J, Koob G (1996) Maintenance of cocaine selfadministration is not affected by pharmacological blockade of brain CRF receptors. Soc Neurosci Abstr 22:925.

Buckingham JC, Cooper TA (1984) Differences in hypothalamicpituitary-adrenocortical activity in the rat after acute and prolonged treatment with morphine. Neuroendocrinology 38:411-417.

Cador M, Cole BJ, Koob GF, Stinus L, Le Moal M (1993) Central administration of corticotropin releasing factor induces long-term sensitization to D-amphetamine. Brain Res 606:181-186.
Chen Y, Mansbach R, Winter S, Brooks E, Collins J, Corman M, Dunaiskis A, Faraci S, Gallaschum J, Schmidt A, Schulz D (1997) Synthesis and oral efficacy of a 4-(butylethylamino)pyrrolo[2,3-D]pyrimidine: a centrally active corticotropin-releasing factor 1 receptor antagonist. J Med Chem 40:1749-1754.

Comer SD, Lac ST, Wyvell CL, Curtis LK, Carroll ME (1995) Food deprivation affects extinction and reinstatement of responding in rats. Psychopharmacology (Berl) 121:150-157.

Deroche V, Marinelli M, Le Moal M, Piazza PV (1997) Glucocorticoids and behavioral effects of psychostimulants. II: Cocaine intravenous self-administration and reinstatement depend on glucocorticoid levels. J Pharmacol Exp Ther 281:1401-1407.

de Wit H, Stewart J (1981) Reinstatement of cocaine-reinforced responding in the rat. Psychopharmacology (Berl) 75:134-143.

Dunn AJ, Berridge CM (1990) Physiological and behavioral responses to corticotropin-releasing-factor: is CRF a mediator of anxiety or stress responses. Brain Res Rev 15:71-100.

Erb S, Shaham Y, Stewart J (1996) Stress reinstates cocaine-seeking behavior after prolonged extinction and a drug-free period. Psychopharmacology (Berl) 128:408-412.

Goeders N, Guerin G (1996a) Effects of surgical and pharmacological adrenalectomy on the initiation and maintenance of intravenous cocaine self-administration in rats. Brain Res 722:145-152.

Goeders N, Guerin G (1996b) Role of corticosterone in intravenous cocaine self-administration in rats. Neuroendocrinology 64:337-348.

Gray T, Bingaman E (1996) The amygdala: corticotropin-releasing factor, steroids, and stress. Crit Rev Neurobiol 10:155-168.

Heinrichs S, Menzaghi F, Schulteis G, Koob G, Stinus L (1995) Suppression of corticotropin-releasing factor in the amygdala attenuates aversive consequences of morphine withdrawal. Behav Pharmacol 6:74-80.

Jaffe JH, Cascell NG, Kumor KM, Sherer MA (1989) Cocaine-induced cocaine craving. Psychopharmacology (Berl) 97:59-64.

Koob GF (1996) Drug addiction: the yin and yang of hedonic homeostasis. Neuron 16:893-896.

Kosten TR, Rounsaville BJ, Kleber HD (1986) A 2.5-year follow-up of depression, life crises, and treatment effects on abstinence among opioid addicts. Arch Gen Psychiatry 43:733-739.

Lavicky J, Dunn AJ (1993) Corticotropin-releasing factor stimulates catecholamine release in hypothalamus and prefrontal cortex in freely moving rats as assessed by microdialysis. J Neurochem 60:602-612.

Makino S, Gold P, Schulkin J (1994a) Corticosterone effects on corticotropin-releasing hormone mRNA in the central nucleus of the amygdala and the parvocellular region of the paraventricular nucleus of the hypothalamus. Brain Res 640:105-112.

Makino S, Gold P, Schulkin J (1994b) Effects of corticosterone on CRH mRNA and content in the bed nucleus of the stria terminalis; comparison with the effects in the central nucleus of the amygdala and the paraventricular nucleus of the hypothalamus. Brain Res 657:141-149.

Marinelli M, Piazza PV, Deroche V, Maccari S, Le Moal M, Simon H (1994) Corticosterone circadian secretion differentially facilitates dopamine-mediated psychomotor effect of cocaine and morphine. J Neurosci 14:2724-2731.

Marinelli M, Rouge-Pont F, De Jesus-Oliveira C, Le Moal M, Piazza P (1997) Acute blockade of corticosterone secretion decreases the psychomotor stimulant effects of cocaine. Neuropsychopharmacology 16:156-161.

McFall ME, Mackay PW, Donovan DM (1992) Combat-related posttraumatic stress disorder and severity of substance abuse in Vietnam veterans. J Stud Alcohol 53:357-363.

Menzaghi F, Heinrichs SC, Merlo Pich E, Weiss F, Koob GF (1993) The role of limbic and hypothalamic corticotropin- releasing factor in behavioral response to stress. Ann NY Acad Sci 697:142-154.

Menzaghi F, Rassnick S, Heinrichs S, Baldwin H, Merlo Pich M, Weiss F, Koob GF (1994) The role of corticotropin-releasing factor in the anxiogenic effects of ethanol withdrawal. Ann NY Acad Sci 739:176-184.

Merlo Pich E, Lorang M, Yeganeh M, Rodriguez de Fonseca F, Raber J, Koob GF, Weiss F (1995) Increase of extracellular corticotropinreleasing factor-like immunoreactivity levels in the amygdala of awake rats during restraint stress and ethanol withdrawal as measured by microdialysis. J Neurosci 15:5439-5447.

Meyer JS, Micco DJ, Stephenson BS, Krey LC, McEwen BS (1979) Subcutaneous implantation method for chronic glucocorticoid replacement therapy. Physiol Behav 22:867-870.

Pavcovich L, Valentino R (1997) Regulation of a putative neurotrans- 
mitter effect of corticotropin-releasing factor: effects of adrenalectomy. J Neurosci 17:401-408.

Paxinos G, Watson C (1986) The rat brain in stereotaxic coordinates. New York: Academic.

Pechnick R (1993) Effects of opioids on the hypothalamo-pituitaryadrenal axis. Annu Rev Pharmacol Toxicol 32:353-383.

Piazza P-V, LeMoal M (1996) Pathophysiological basis of vulnerability to drug abuse: interaction between stress, glucocorticoids and dopaminergic neurons. Annu Rev Pharmacol Toxicol 36:359-378.

Piazza P-V, Maccari S, Deminière J-M, LeMoal M, Mormède P (1991) Corticosterone levels determine individual vulnerability to amphetamine self-administration. Proc Natl Acad Sci USA 88:2088-2092.

Piazza PV, Marinelli M, Jodogne C, Deroche V, Rougé-Pont F, Maccari S, Le Moal M, Simon H (1994) Inhibition of corticosterone synthesis by Metyrapone decreases cocaine-induced locomotion and relapse of cocaine self-administration. Brain Res 658:259-264.

Piazza P, Rouge-Pont F, Deroche V, Maccari S, Simon H, Le Moal M (1996) Glucocorticoids have state-dependent stimulant effects on the mesencephalic dopaminergic transmission. Proc Natl Acad Sci USA 93:8716-8720.

Sakai RR, Ma LY, He PF, Fluharty SJ (1995) Intracerebroventricular administration of angiotensin type $1\left(\mathrm{AT}_{1}\right)$ receptor antisense oligonucleotides attenuate thirst in the rat. Regul Pept 59:183-192.

Sarnyai Z, Biro E, Penke B, Telegdy G (1992) The cocaine-induced elevation of plasma corticosterone is mediated by endogenous corticotropin-releasing factor (CRF) in rats. Brain Res 589:154-156.

Sarnyai Z, Biro E, Gardi J, Vecsernyés M, Julesz J, Telegdy G (1995) Brain corticotropin-releasing factor mediates "anxiety-like" behavior induced by cocaine withdrawal in rats. Brain Res 657:89-97.

Self DW, Barnhart WJ, Lehman DA, Nestler EJ (1996) Opposite modulation of cocaine-seeking behavior by D1- and D2-like dopamine receptor agonists. Science 271:1586-1589.

Self D, Genova L, Hope B, Barnhart W, Spencer J, Nestler E (1998) Involvement of cAMP-dependent protein kinase in the nucleus accumbens in cocaine self-administration and relapse of cocaine-seeking behavior. J Neurosci 18:1848-1859.

Shaham Y, Stewart J (1995) Stress reinstates heroin-seeking in drug-free animals: an effect mimicking heroin, not withdrawal. Psychopharmacology (Berl) 119:334-341.
Shaham Y, Stewart J (1996) Effects of opioid and dopamine receptor antagonists on relapse induced by stress and re-exposure to heroin in rats. Psychopharmacology (Berl) 125:385-391.

Shaham Y, Funk D, Erb S, Brown T, Walker C-D, Stewart J (1997) Corticotropin-releasing factor, but not corticosterone, is involved in stress-induced relapse to heroin-seeking in rats. J Neurosci 17: 2605-2614.

Shaham Y, Erb S, Leung S, Buczek Y, Stewart J (1998) CP- 154,526, a selective, nonpeptide antagonist of the corticotropin-releasing factor type 1 receptor attenuates stress-induced relapse to drug seeking in cocaine- and heroin-trained rats. Psychopharmacology (Berl) 137: 184-190.

Shiffman S, Wills TA (1985) Coping and substance abuse. Orlando, FL: Academic.

Stewart J (1984) Reinstatement of heroin and cocaine selfadministration behavior in the rat by intracerebral application of morphine in the ventral tegmental area. Pharmacol Biochem Behav 20:917-923.

Stewart J, Vezina P (1988) A comparison of the effects of intraaccumbens injections of amphetamine and morphine on reinstatement of heroin intravenous self-administration behavior. Brain Res 457:287-294.

Swanson LW, Simmon DM (1989) Differential steroid hormone and neural influences on peptide mRNA levels in CRH cells of the paraventricular nucleus: a hybridization histochemical study in the rat. J Comp Neurol 285:413-435.

Torres G, Rivier C (1992) Differential effects of intermittent or continuous exposure to cocaine on the hypothalamic-pituitary-adrenal axis and c-fos expression. Brain Res 571:204-211.

Valentino RJ, Foote SL, Page ME (1993) The locus coeruleus as a site for integrating corticotropin-releasing factor in behavioral responses to stress. Ann NY Acad Sci 697:173-188.

Wise RA, Murray A, Bozarth MA (1990) Bromocriptine selfadministration and bromocriptine-reinstatement of cocaine-trained and heroin-trained lever pressing in rats. Psychopharmacology (Berl) 100:355-360.

Worley CM, Valdez A, Schenk S (1994) Reinstatement of extinguished cocaine-taking behavior by cocaine and caffeine. Pharmacol Biochem Behav 48:217-221. 